\title{
Appraising Public Value in the Public Sector: Re-evaluation of the Strategic Triangle
}

\author{
Malang B.S. Bojang (D) 1* \\ ${ }^{1}$ Faculty of Economics and Administrative Sciences, Political Science and Public \\ Administration Department, Umuttepe Campus, Kocaeli, Turkey \\ * Corresponding author: malangbsbojang@gmail.com
}

\begin{abstract}
Article History
Received 2021-01-15

Revised 2021-02-01

Accepted 2021-02-02

Published 2021-02-03

\section{Keywords}

Public value,

performance measurement,

public sector,

strategic triangle

\section{How to cite?}

Bojang, M. B. S. (2021). Appraising

Public Value in the Public Sector: Re-

Evaluation of the Strategic Triangle.

SEISENSE Journal of Management,

4(2), 1-10. doi: 10.33215/sjom.v4i2.551
\end{abstract}

Purpose- This article aims to address public value by assessing public programs and services' success in a more cost-effective way. The study also investigates how public managers and elected officials can use public value to guide their decisions on resource allocation to create value for the citizens.

Design/methodology- To meet this study's aims, Mark Moore's strategic triangle is used as the framework for this study. This is a comprehensive framework that evaluates the performance of public sector programs and service delivery. Data for this study has been collected via a primary scoping of the literature on public value. Database searches were conducted in the Social Sciences Index, SCOPUS journals, ISI Social Sciences Citation Index, and Google Scholar.

Findings- From the investigation, the result indicates that public value is created by government or public managers in their daily transactions and by non-profit organizations that articulate their objectives and find popular support for the community's common good.

Practical implications- Arguably, public value management provides a necessary improvement to public management theories. It redefines the function of public sector managers in the provision of socially desirable outcomes through citizen engagement. As a progress appraisal tool in public organizations, it offers a broader and inclusive framework than the New Public Management (NPM).

Originality/value- This study's results contribute to the knowledge and literature of public value in the public sector. The strategic triangle builds on the challenges and weaknesses of NPM and it aims at reshaping institutions to prioritize value creation for citizens. 


\section{Introduction}

Professor Mark H. Moore has initiated research on the way managers in the public sector can involve communities in assisting and legitimizing their work in public sector organizations. In his book title, 'Creating Public Value,' Moore (1995) describes public value equivalent to private sector organizations' private value. The only difference he argued was that while the private sector aims to maximize profit (shareholder value), public organizations act in the community's best interests (public value). The assumption that benefits are distributed equally in the public sector and public responsibilities sanctioned is as significant as the attainment of socially desirable outcomes or individual satisfaction (EY Report, 2014). Public value creation is structured to get managers thinking about what programs and services are most treasured to society cost-effectively. It is a means of improving quality decision-making through public managers' engagement with the citizens and users of the public services, thus encouraging trust in public sector organizations (Moore, 1995; EY Report, 2014).

Public value as an emerging paradigm is gradually an omnipresent concept in public management discourse and has been highlighted in public sector development programs (Williams \& Shearer, 2011). Several scholars have claimed that public value provides a broader measurement perspective than the classical bureaucratic machinery and New Pubic Management (NPM) (Benington, 2009; Bonina \& Cordella, 2008; Moore, 1995; Stoker, 2006). It has been signaled as a 'third way' beyond classical public management and NPM. This is because it focuses on many of the modern-day challenges public institutions faced in the public sector. Fair distribution of resources, authorize decision-making, and performance measurement are some of these challenges (Hills \& Sullivan, 2008). Public value provides a comprehensive tool to measure inputs and outcomes of public programs and services in an authorized manner. Kelly et al., (2002) define these multifaceted assessment requirements in their Cabinet Office paper as:

\section{"... as contemporary and wider appraisal tool within the NPM literature, covering not only socially desirable outcomes but also the means used as well as trust and legitimacy. It focuses on issues such as equity, ethos, and accountability" (Kelly et al., 2002).}

This indicates that value in the public sector epitomizes an all-inclusive concept of public management and programs. It seeks to appraise a broader diversity of issues than other methods and that procedures are as vital as social outcomes. To this end, this research aims to address the public value approach to assessing the success of public programs and services in a more cost-effective way. The study also investigates how public managers and elected officials can use public value to guide their decision on resource allocation to create value for the citizens. Therefore, this article seeks to answer the following questions: Is public value a useful performance tool to gauge public services and programs? Who has the legitimate authority to create public value in a democratic society? How can the strategic triangle be used as a guide to gauge the performance of government programs and actions? To meet this paper's purposes and sufficiently answer the research questions, the strategic triangle is employed as the research framework. This is a comprehensive framework to evaluate public sector programs and service delivery (Alford \& O’Flynn, 2009; Bojang, 2020; Kelly et al., 2002; O’Flynn, 2007). The paper is organized into three-folds. The first section sets out the principles, practices, and premises of public value creation and measurement in the public sector. This is followed by a brief discussion on the research methodology. The final section re-examined the strategic triangle, which serves as a guide for public sector managers 


\section{Literature Review}

\section{The Public Value Creation in the Public Sector}

The concept of public value has seen a tremendous interest in academia and practitioners alike recently. Ever since Moore's (1995) influential contribution, the idea of public value management offers an inspirational viewpoint on the function of the government (Benington, 2009; Moore, 1995) and a productive substitute area of study to better comprehend public institutions (Cordella \& Bonina, 2012). Despite the growing acceptance of public value, yet it lacks a universally accepted definition. This is due to the normativity and variability of contending understandings of the term 'public value'; its meaning and applications are vigorously contested (Jørgensen \& Bozeman, 2007; Stoker, 2006; Williams \& Shearer, 2011). This ambiguous nature of public valueled several advocates to argue that it ought to be perceived as a paradigm (Benington, 2009; Stoker, 2006), as a concept (Kelly et al., 2002), a model (O’Flynn, 2007). Rhodes \& Wanna (2007) strongly criticized public value vagueness, which they believe energies its approval because 'it is all things to all people.' On this background, public value is those "normative agreement about (a) the rights, benefits, and privileges that every citizen ought to be entitled; (b) the responsibilities of citizens to their society, government and to each other; and (c) the values on which government policies ought to be based on" (Bozeman 2007:13). This conceptualization of public value is much broader and incorporates private and public activity (Mazzucato \& Ryan-Collins, 2019).

Moore's initial work revolves around three subjects. The function of administration in society, the responsibility of public sector managers in government, and the strategies employed by them to create the most valuable for the society (Cordella \& Bonina, 2012). The public value paradigm argues for a fundamental change in the public institutions as it conveys government programs at the center and seeks solutions to meet citizens' expectations. A public sector aiming for value creation should focus on performance management practices by providing a fair and equitable society. According to Stoker (2006), politics is very significant in performance management practice. It influences the foundation for co-operation by changing people's preferences and generating an environment where partnership is possible. For Stoker, it is precisely politics that energies the procedure of value creation in the public sector. Therefore, the political process cannot be disentangled from public management practices.

Similarly, the study by Moore (1995) acknowledges this by stating that "managers ought to be understood as explorers who aims to discover, describe and create public value” (Moore, 1995:21). Moore (1995) suggests managers in the public sphere replace politicians, and be involved in the partisan process, to be the new platonic guardians and judges of the common good. This approach of public value creation is what Rhodes \& Wanna (2007) criticize.

Public value stresses the critical role play by the public managers to mediate the necessity for well-organized service provision and citizens' participation in designing public policies (Mazzucato \& Ryan-Collins, 2019). Accordingly, public value goals can only be realized via a partnership between private and public sectors, which together, through the procedure of innovation, co-produce, and co-shape markets (Mazzucato 2016). In essence, public value creation strategies ought to go beyond borrowing simple private sector models and market practices. Instead, public sector managers have to consider three issues simultaneously: legitimacy and support, operational capabilities, and public value (Moore, 1995). Kelly et al. (2002) advanced a detailed conception of value source as services, outcomes, and trust. These three-value sources are all significant in public value creation. 'Trust is the most important because even if the government provides or meets citizens' expectations, a mere lack of trust will destroy public value. Public value gives relative importance to value-laden outcomes and citizens' engagement in the democratic process (Blaug et al., 2006). Public value is profoundly democratic because it requires public sector organizations to discuss value creation in the public sector. 
Using government resources to produce public value or public good for society is inspiring because it concentrates on the collective. The public value paradigm contends that an individual's perceptions and preferences cannot be aggregated into what society wants from the government. Through their elected officials, collective citizens decide what they value, and these shared preferences echo what is treasured when the government's policy is concerned. Therefore, the public value cannot be well-defined by the producers but rather by the collective 'WE' (citizens) that consume it (Alford \& Hughes, 2008; Cordella \& Bonina, 2012). Unlike private values that seek to fulfill individual desires, public values satisfy not just ends but also achieving social outcomes for collective 'We.' In public value creation, the objective of public services should be spellout, together with the participation of the public in the process of determining what is valuable for the citizens. For instance, appraising how effective and efficient we are using government resources depends on defining public value (EY Report, 2014). The public value approach suggests us to distinguish between means use in public value creation and the ends we seek to attain. What is vital in public value approaches is what works to create social outcomes and satisfy citizens. There is no single right way, but there is a suitable outcome.

The idea of public sector value as argue by Moore (1995) is that the central role of public managers are to scout for prospects of value creation just as private sector executive does. The creation of public value is defined by the action of what government officials do and how they do it (Alford \& O’Flynn, 2009; Moore, 1995; Stoker, 2006). The study by Meynhardt (2009) took a psychological account to comprehend the whole idea of public sector value. From the basis of needs theory, Meynhardt (2009) proposes four essential elements related to the public value landscape: "subject, object, basis of evaluation, and character of evaluation" (Meynhardt, 2009:200). This link with Moore's (1995) assumption that public value is rooted in an individual's desires. For Meynhardt (2009), "public value starts and ends with the individual." To put it more clearly, value creation in the public sector is about how people think and feel about society.

There has been extensive evidence in the literature that value is produced by government organizations and non-profit organizations (Alford \& Hughes, 2008; Bojang, 2020; Bozeman, 2019; Jørgensen \& Bozeman, 2007; Meynhardt, 2009), as seen in the conclusion of Jørgensen \& Bozeman (2007) that "public value is not governmental" (Jørgensen \& Bozeman, 2007:372). This researcher also shares the same opinion that public value cannot be restricted to a government institution. Still, the private and social sectors do also contribute to public value creation. More emphasis should be on who consumes public value and not who produces it (Alford \& Hughes, 2008). As Moore argues, what the citizens' value collectively is the public value (Moore, 1995). Equally, it is not enough for public sector organizations to create what is valuable to the citizenry; the desirable results must outweigh the cost involved. "Only then can we be sure that some public value has been created" (Moore, 1995:29).

\section{Measuring Public Sector Performance}

The public value approach seeks to reformulate classical public management and NPM within public administration discourse (Turkel \& Turkel, 2016). An indication that public management scholarship is moving beyond the old management system and NPM towards the public value paradigm meets contemporary challenges of public policies (Benington, 2009; Bojang, 2020; Moore, 1995; O'Flynn, 2007). From the challenges and experiences of NPM in the 1990s, there has been an ideological shift from market practices to government. The 'post-competitive' approach focuses on outcomes and efficiency for attaining broader governmental goals (O'Flynn, 2007). Public value gives a more accurate viewpoint for contemporary institutional challenges than NPM approaches (Meynhardt, 2009). Similarly, Jørgensen \& Bozeman concluded that public value is the most significant concept in administration discourse and policy studies (Jørgensen \& Bozeman, 2007:355). For Alford \& Hughes (2008), 'public value pragmatism' is the next public management movement. 
Conventional performance measurement tool like NPM draws more on the narrow economic model than public value provides. As a means of appraising progress in the public sector, the public value provides a much broader perspective (Bojang, 2020; Kelly et al., 2002; Stoker, 2006; Talbot, 2017). It is a benchmark used to evaluate development and progress in public organizations, their decision-making process, and the distribution of available resources for effective delivery of services (O'Flynn, 2007). For Mazzucato \& Ryan-Collins (2019), public value is a way of assessing advancement towards attaining broader societal goals. In a similar vein, public value puts the public first through citizens' engagement and civic discovery of public interest. Democratic process and public discussion are the currency of the public sector's value cycle (Mazzucato \& Ryan-Collins, 2019). Public sector managers, civic participation, and democratic deliberation provide a useful tool for acceptable public policy and value creation (Sandfort and Quick, 2015).

Public value is not only created by the government through services, laws, and regulations (Kelly et al., 2002) but is also determined by perceptions and preferences of citizens, articulated over a plethora of ways (Mazzucato \& Ryan-Collins, 2019). This implies that public sector organization can maintain their performance by satisfying citizens via public value (Yotawut, 2018). Public value is an appraisal tool that intensifies the idea of public services. It requires public sector managers to consider cost in service provision and the impact of government activities on the civic life of citizens. As a measurement tool, it focuses on the net benefit of government programs and services. The literature on public value centers on those values that ought to guide public officials, policies, and organizations (van der Wal \& van Hout, 2009). Moore emphasizes that public value is a set of measurements used to evaluate the performance of public programs. Therefore, government programs and services can be measured using the concept of public value (Moore, 1995; Rutgers \& Overeem, 2014). According to Nabatchi (2018), from the state's perspective, "public sector value describes an assessment of what is produced and continued by the government for the public." Arguably, public value by far provides a modest instrument over public interest as a diagnostic device (Bozeman, 2019; Fukumoto \& Bozeman, 2019).

Several scholars have argued that public value provides a more inclusive framework to gauge public programs and services, especially from the citizen's standpoint (Alford \& O'Flynn, 2009; Kelly et al., 2002; Talbot, 2017). The framework of public value can be used to justify the use of public resources and at the same time offers practical guidance to public sector managers. It replaces consumers as used in NPM to citizens and policy decision-making backed by the democratic political process. As Mazzucato \& Ryan-Collins (2019) asserted, it reconcile the long-standing tension between bureaucracy and democracy.' Public managers ought to innovate and enhance services to the public and at the same time improve the value of their service delivery to the public (Rhodes \& Wanna, 2007). However, the public management framework's implication as a performance management tool is that the community must be an active contributor in the assessment to be successful. Again, public value measurement is complicated because value creation occurs at the end of the value cycle; perhaps people's lives improve after many years the policy was enacted (Mazzucato \& Ryan-Collins, 2019).

Putting public value at the forefront of performance measurement presents a broader benefit of governmental activities. Speaking more broadly, the concept replaces NPM to redefined the function of public managers and reshaped the function of public administration institutions (Ćwiklicki, 2016; O’Flynn, 2007; Spano, 2009; Stoker, 2006). In present-day public administration, it is not enough to deliver social outcomes. Achieving institutional trust and legitimacy is tremendously essential in public administration (Ćwiklicki, 2016). This is in conjunction with Moore's proposition, which focuses more on public management quality and less value.

\section{Methodology}

This paper aims to address the public value approach to assessing public programs' success in a more costeffective way. The study also investigates how public managers and elected officials can use public value to guide their decision on resource allocation to create value for the citizens. Therefore, this article seeks to answer 
the following questions: Is public value a useful performance tool to gauge public services and programs? Who has the legitimate authority to create public value in a democratic society? How can the strategic triangle be used as a guide to gauge the performance of government programs and actions? To meet the purposes of this study and sufficiently answer the research questions, the strategic triangle developed by Moore (1995) is employed as a framework for this study. This is a comprehensive framework to evaluate public sector programs and service delivery (Alford \& O’Flynn, 2009; Bojang, 2020; Kelly et al., 2002; O’Flynn, 2007). According to Moore's strategic framework, public sector managers must be skillful in organizing market activity to create the anticipated value-i.e., they must balance: Valuable vs. Authorizable vs. Doable (EY Report, 2014). The threedimensional strategic framework developed by Moore (1995) is discussed in detail below.

Data for this study has been collected via a primary scoping of the literature on public value. Database searches were conducted in the Social Sciences Index, SCOPUS journals, ISI Social Sciences Citation Index, and Google Scholar. They were employing and searching the terms 'public value', 'public value management,' 'performance management,' and 'public sector management' in conjunction. Research articles, policy documents, and working papers were selected from in-depth searching.

\section{Strategic Triangle in Public Sector Organization}

The underlined assumption of public value theory is that public managers should find opportunities to create what the society most value, just like shareholder value created by the private sector executive (Moore, 1995). Public value is an innovative way of thinking about public administration on how to improve public service. It is a way of understanding what the 'public' values (Moore, 1995). Public sector managers should act and think strategically to produce public value for individuals and collectively for society. This value is delivered via delivering public services to the citizens (Bonina \& Cordella, 2008; Moore, 1995). Public value is management thinking that focuses not only on efficiency but also on meeting the expectations of society as a whole. It is an alternative governance model responding to old public management's failures and the NPM paradigm (Sami et al., 2018).

The public value paradigm can appraise public programs and services' performance because of its quality and inclusiveness. Because of its usefulness, public value is popular in both advanced and developing countries. As an emerging paradigm, public value evaluates government actions and policies (Alford \& O'Flynn, 2009; Bojang, 2020; Kelly et al., 2002). From the strategic management point of view, public value literature indicates two distinct views. First, public value as a normative concept should define government responsibility and citizens' rights and obligations. Second, citizens' willingness and acceptance of rights, duties, privileges, and obligations upon them. Moore (1995) proposes the strategic triangle (as a guide for public managers), which is both administratively feasible and wins public and government approval (Jacobs, 2014). Accordingly, the strategic triangle underscores tripartite demands on public sector managers: upwards over organizational and political structures, downwards via the management and operational lines, and outwards to the public (Moore, 1995). The public manager's goal ought to be to align the three points of the triangle. Below is the strategic triangle proposed by Mark H. Moore. 


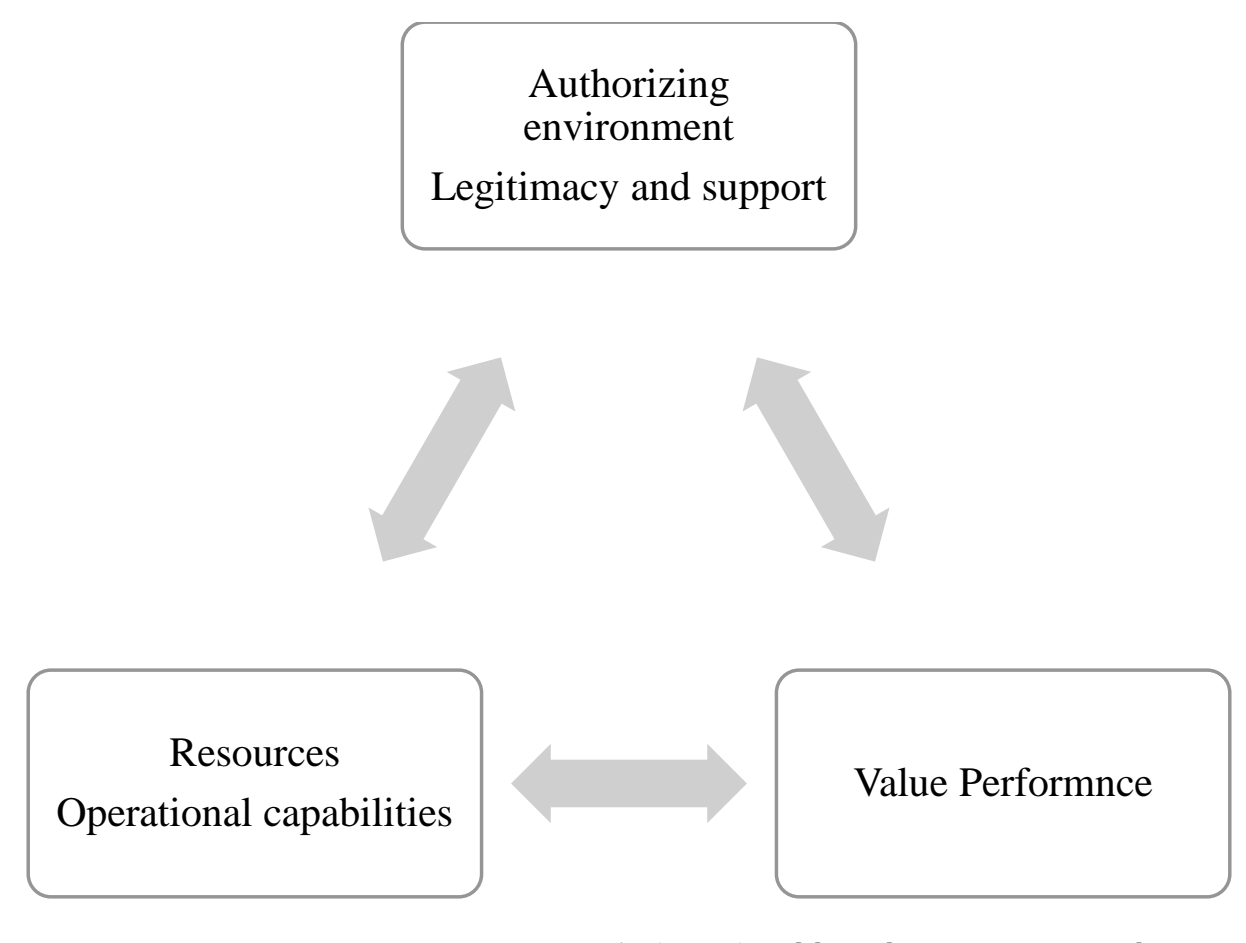

Figure 1: Moore's (1995) public value strategic triangle

For Moore, public managers' main role is to create public value that the public can only judge. From the strategic framework mentioned above, public value can be created via management trade-offs of three dimensions: (a) the determination of value which government seeks to create; (b) the 'bases of legitimacy and support' that are relied upon to sanction the government to take action; and (c) the resources essential to sustain the effort to generate that value (Mazzucato \& Ryan-Collins, 2019). Moore contends that managers in the public sector have to reflect on the three dimensions at the same time to deliver the most anticipated value for the citizens. Dimensions in the strategic triangle are all intertwined in the role and function of the public manager, and his/her job is to maintain balance. Legitimacy and support guarantee the cooperation and flow of public funds coupled with wider approval from the public. Operational capabilities stress the availability of resources for the provision of public services value by the citizens. Public value is the most sought by citizens, depending on their experience, perception, and expectation. The British Cabinet Office expounded Moore's strategic triangle due to its practical viability (Ćwiklicki, 2016).

Kelly et al. (2002) interpret Moore's strategic triangle into services, outcomes, and trust. These building blocks resemble Moore's 'value circle,' 'authorizing environment,' and 'operational capability' (Williams \& Shearer, 2011). Under the strategic triangle framework, public managers ought to think beyond mere policy implementation to more innovation and entrepreneurialism. Public managers have to adapt to the external environment via the engagement of the public. For a strategic organization in the public sector, public officials must consider the following issues:'(a) What is the central and essential value you are looking to create? (b) What agency or institution can authorize legitimacy and support or provide the necessary resources for value creation? (c) Does the agency has the operational capabilities needed to deliver this result?' (Moore, 1995; EY Report, 2014). However, strategic management is for public managers to imagine and articulate the public value in a legitimate, operationally doable, and supportive way (Moore, 1995). 


\section{Conclusion}

The notion of public value is gaining popularity among practitioners and scholars due to its inclusiveness in appraising government policies and programs. This popularity is real in many developed countries as it aims to respond to the challenges and weaknesses of NPM in the 1990s. The concept of public value has now entered its maturity phase, and it clearly defines the role of public managers in providing socially desirable outcomes. This study aims to evaluate public programs and services' success more cost-effectively through the public value approach. The study also investigates how public managers and elected officials can use public value to guide their decision on resource allocation and hence create value for the citizens. This paper argues that public value provides a broader and inclusive appraisal tool than the conventional market-led approach. The adoption of public value presents a paradigmatic change in public administration. This transformation re-echoes the role of public managers to meet contemporary governance challenges.

From the investigation, the result indicates that public value is created by government or public managers in their daily transactions and by non-profit organizations that articulate their objectives and find popular support for the common good of the community. This finding corresponds with Moore's conclusion on who creates public value. Moore (1995) claims that:

\section{"...defining 'public value' needs the active deliberation of not only citizens but also market and social sectors, including NGOs. Any sector that is interested in the collaborative development of society should be involved in deciding what is valuable, how to produce it, and how it should be measured"(Moore, 1995).}

The strategic triangle proposed by Moore can be a useful tool at the disposal of public managers to create opportunities that go beyond the policy implementation role to value production for citizens. Public value management stresses public sector invention and the worth of managers in the public sector. It is best viewed as a means employed by public managers to recognize and implement operational developments in the public sector organization. However, measuring public value remains problematic due to its elusiveness. The term 'Value' is a problem in itself as it is relative. This is because the value position of the individual citizen is subjected to change with time.

Further, Moore (1995) argues for managers to be platonic guardians of public interest. This position appears problematic because bureaucrats are motivated by self-interest who can turn the table in their favor. As Rhodes \& Wanna (2007) asserted, it is a repackaging of bureaucratic self-interest. While the strategic triangle provides the starting point for evaluating and guiding public managers, the paper recommends its extension and a more robust public value measurement framework, especially toward the management control system.

Funding: This research received no external funding.

Acknowledgments: Special appreciation to Assoc. Prof. Tuba Kanci, Assoc. Prof. Oktay Koc, and Asist. Prof. Dr. Yasin Kerem Gumus for their advice and support.

Conflicts of Interest: The author declares no conflict of interest.

\section{References}

Alford, J., \& Hughes, O. (2008). Public value pragmatism as the next phase of public management. American Review of Public Administration, 38(2), 130-148. https://doi.org/10.1177/0275074008314203

Alford, J., \& O’Flynn, J. (2009). Making sense of public value: Concepts, critiques and emergent meanings. International Journal of Public Administration, 32(3-4), 171-191. https://doi.org/10.1080/01900690902732731 
Benington, J. (2009). Creating the public in order to create public value? International Journal of Public Administration, 32(3-4), 232-249. https://doi.org/10.1080/01900690902749578

Blaug, R., Horner, L., \& Lekhi, R. (2006). Public value, politics and public management. A Literature Review. London: Work Foundation, March, 1-62.

Bojang, M. B. S. (2020). Beyond New Public Management Paradigm: The Public Value Paradigm and Its Implications for Public Sector Managers. Journal of Public Value and Administrative Insight, 3(2), 110. https://doi.org/10.31580/jpvai.v3i2.1381

Bonina, C., \& Cordella, A. (2008). The new public management, e-government and the notion of public value: lessons from Mexico. Proceedings of SIG GlobDev's First Annual Workshop, Paris, France. http://www.researchgate.net/publication/228861512_The_new_public_management_egovernment_and_the_notion_of_'public_value'_lessons_from_Mexico/file/72e7e5267718664ed0.pd $\mathrm{f}$

Bozeman, B. (2019). Public values: citizens' perspective. Public Management Review, 21(6), 817-838. https://doi.org/10.1080/14719037.2018.1529878

Bozeman, B. 2007. Public Values and Public Interest: Counterbalancing Economic Individualism. Washington: Georgetown University Press.

Cordella, A., \& Bonina, C. M. (2012a). A public value perspective for ICT enabled public sector reforms: A theoretical reflection. Government Information Quarterly, 29(4), 512-520. https://doi.org/10.1016/j.giq.2012.03.004

Cordella, A., \& Bonina, C. M. (2012b). A public value perspective for ICT enabled public sector reforms: A theoretical reflection. Government Information Quarterly, 29(4), 512-520. https://doi.org/10.1016/j.giq.2012.03.004

Ćwiklicki, M. (2016). Comparison of public value measurement frameworks. Zarządzanie Publiczne, 1(1(35)/2016), 20-31. https://doi.org/10.15678/zp.2016.35.1.02

Fukumoto, E., \& Bozeman, B. (2019). Public Values Theory: What Is Missing? American Review of Public Administration, 49(6), 635-648. https://doi.org/10.1177/0275074018814244

Hills, D., \& Sullivan, F. (2008). Measuring public value 2: Practical approaches. The Work Foundation. www.theworkfoundation.com

Jacobs, L. R. (2014). The contested politics of public value. Public Administration Review, 74(4), 480-494. https://doi.org/10.1111/puar.12170

Jørgensen, T. B., \& Bozeman, B. (2007). Public Values. Administration \& Society, 39(3), 354-381. https://doi.org/10.1177/0095399707300703

Kelly, G., Mulgan, G., \& Muers, S. (2002). Creating Public Value: An analytical framework for public service reform. Strategy Unit, Cabinet Office, UK Government, 1-35. http://webarchive.nationalarchives.gov.uk/20100416132449/http:/www.cabinetoffice.gov.uk/media /cabinetoffice/strategy/assets/public_value2.pdf

Mark H. Moore. (1995). Creating-Public-Value-Strategic-Management-in-Government.pdf.

Mazzucato, M., \& Ryan-Collins, J. (2019). Putting value creation back into "public value": from market-fixing to market-shaping | UCL Institute for Innovation and Public Purpose. UCL Institute for Innovation and Public Purpose.

Mazzucato, M. (2016). From market fixing to market-creating: A new framework for innovation policy. Industry and Innovation, 23(2), pp. 140-156.

Meynhardt, T. (2009). Public value inside: What is public value creation? International Journal of Public Administration, 32(3-4), 192-219. https://doi.org/10.1080/01900690902732632

Nabatchi, T. (2018). Public values frames in administration and governance. Perspectives on Public Management and Governance, 1, 59-72.

O’Flynn, J. (2007). From new public management to public value: Paradigmatic change and managerial 
implications. Australian Journal of Public Administration, 66(3), 353-366. https://doi.org/10.1111/j.1467-8500.2007.00545.x

Rhodes, R. A. W., \& Wanna, J. (2007). The limits to public value, or rescuing responsible government from the platonic guardians. Australian Journal of Public Administration, 66(4), 406-421. https://doi.org/10.1111/j.1467-8500.2007.00553.x

Rutgers, M. R., \& Overeem, P. (2014). Public Values in Public Administration. Journal of Public Administration Research and Theory, 24(3), 806-812. https://doi.org/10.1093/jopart/muu017

Sami, A., Jusoh, A., Nor, K. M., Irfan, A., \& Qureshi, M. I. (2018). Journal of Public Value and Administration Insights (JPVAI) Systematic Review of Public Value. Journal of Public Value and Administration Insights (JPVAI), 1(1), 1-6. https://doi.org/10.31580/jpavi.v1i1.136

Sandfort, J \& Quick, K.S. (2015). Building deliberative capacity to create public value: the practices and artifacts of the Art of Hosting. In J. Bryson, L. Bloomberg, \& B. Crosby (Eds.), Public Administration and Public Value (pp. 39-52). Washington, DC: Georgetown University Press.

Spano, A. (2009). Public value creation and management control systems. International Journal of Public Administration, 32(3-4), 328-348. https://doi.org/10.1080/01900690902732848

Stoker, G. (2006). Public value management: A new narrative for networked governance? American Review of Public Administration, 36(1), 41-57. https://doi.org/10.1177/0275074005282583

Talbot, C. R. (2017). Measuring Public Value - a competing values approach A competing values approach. March. https://doi.org/10.13140/RG.2.2.36824.90888

Turkel, G., \& Turkel, E. (2016). Public Value Theory: Reconciling Public Interests, Administrative Autonomy and Efficiency. Review of Public Administration and Management, 4(2). https://doi.org/10.4172/2315-7844.1000189

van der Wal, Z., \& van Hout, E. T. J. (2009). Is public value pluralism paramount? The intrinsic multiplicity and hybridity of public values. International Journal of Public Administration, 32(3-4), 220-231. https://doi.org/10.1080/01900690902732681

Williams, I., \& Shearer, H. (2011). Appraising public value: Past, present and futures. Public Administration, 89(4), 1367-1384. https://doi.org/10.1111/j.1467-9299.2011.01942.x

Yotawut, M. (2018). Examining progress in research on public value. Kasetsart Journal of Social Sciences, 39(1), 168-173. https://doi.org/10.1016/j.kjss.2017.12.005 